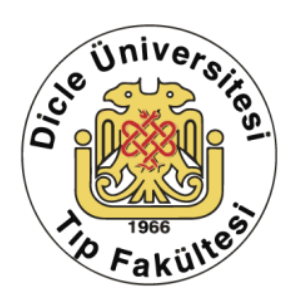

\title{
The Evaluation of Quality of Life of Relatives Caring for Patients with Parkinson's Disease
}

\author{
Faruk Ömer Odabaş ${ }^{1}$, Ali Ulvi Uca ${ }^{2}$
}

1 University of Health Sciences, Konya Health Application and research center, Department of Neurology, Konya, Turkey, ORCID: 0000-0001-9136-9388 2 Necmettin Erbakan University, Meram faculty of medicine, Department of Neurology, Konya, Turkey, ORCID: 0002-5783-8061

Received: 17.02.2018; Revised: 08.03.2018; Accepted: 22.03.2018

\begin{abstract}
Objective: To evaluate quality of life (QoL) of relatives taking care of patients with idiopathic Parkinson's disease (IDP).

Methods: Sixty patients with IPD and 60 patients' relatives were included into the study, and 50 healthy individuals consisted of the controls. In the study group, the Unified Parkinson's Disease Rating Scale (UPDRS)scores and the Hoehn-Yahr Scale (HYS) stages were determined. Depression levels of the IPD patient's relatives and the controls were measured using the Beck Depression Inventory (BDI), while pain and fatigue levels were found via the Visual Analogue Scale (VAS), and QoL was assessed with shorth form-36 (SF-36).

Findings: When the relatives of patients with IPD were compared with the controls, a statistically significance was found between pain, fatigue and depression levels and SF-36 physical and mental component scores. While a positive correlation was observed between patient's UPDRS scores, and relatives' BDI, pain and fatigue levels, a negative correlation was found between SF-36 component and SF-36 physical component scores in these groups.

Conclusions: Decreasing QoL significantly, IPD is a disorder affecting considerably both patients and their relatives' lives and not only patients but also their relatives are influenced from the condition on a large scale. As the disease progresses, the influence becomes defined and an increase is seen in clinical findings while a decrease is witnessed in QoL of IPD patients and their relatives.
\end{abstract}

Keywords: Parkinson's disease, load on patients' relatives, quality of life, depression.

DOI: $10.5798 /$ dicletip.410262

Yazışma Adresi / Correspondence: Faruk Ömer Odabaș, University of Health Sciences, Konya Health Application and research center, Department of Neurology, Konya, Turkey, e-mail: fodabas2002@yahoo.com 


\section{Parkinson Hastalarına Bakım Veren Bireylerde Yaşam Kalitesinin Değerlendirilmesi}

Öz

Amaç: Parkinson hastalarına bakım veren bireylerde yaşam kalitesinin değerlendirilmesi.

Yöntemler: Vaka grubuna 60 idiopatik parkinson hastası ( IPH ) ile 60 bakım veren birey ve kontrol grubuna 50 sağlıklı birey dahil edildi. Hasta grubunda Birleşik Parkinson Hastalığı Derecelendirme Ölçeği (The Unified Parkinson's Disease Rating Scale -UPDRS ) skorları ve Hoehn-Yahr evreleri (HYE) belirlendi. IPH'larına bakım verenlerin ve kontrol grubunun depresyon düzeyleri Beck Depresyon Ölçeği (BDİ) ile, ağrı ve yorgunluk düzeyleri Vizüel Analog Skala (VAS) ile, yaşam kaliteleri shorth form-36 (SF-36) ile değerlendirildi.

Bulgular: İPH’ na bakım veren grup ile kontrol grubu karşılaştırıldığında; ağrı, yorgunluk, depresyon düzeyleri, SF-36 fiziksel ve mental kompanent skorları arasında istatistiksel olarak anlamlı fark bulundu. Hasta grubunda UPDRS skorları ile bakım verenlerin BDİ, ağrı ve yorgunluk düzeyleri ile pozitif yönde korelasyon, SF-36 mental kompanent skoru ve SF-36 fiziksel kompanent skoru ile negatif yönde korelasyon tespit edildi.

Sonuç: İPH; hasta ve bakım verenlerin hayatını önemli ölçüde etkileyen ve yaşam kalitesini anlamlı düzeyde düşüren bir hastalıktır. Hastalıktan sadece hastalar değil hasta yakınları ve bakım veren bireyler de önemli düzeyde etkilenmektedir. Bu etkilenme hastalığın ilerlemesi, klinik bulguların artışı ile belirginleşmekte ve hem hastalarda hem de bu hastalara bakım veren bireylerde yaşam kalitesini düşürmektedir.

Anahtar kelimeler: Parkinson hastalığı, bakım veren yükü, depresyon, yaşam kalitesi.

\section{INTRODUCTION}

Among neurodegenarative disorders, Parkinson's disease (IPD) is the second most commonly encountered disease after Alzheimer's ${ }^{1}$. Average onset of IPD ranges between $60-80$. The condition affects nearly $1 \%$ of general population over 65 years of age and average period between the times of diagnosis and death is some 15 years $^{2}$. IPD is characterized by such motor symptoms as bradykinesia, rigidity, tremor and postural instability ${ }^{3}$. Although motor symptoms of IPD are superior to clinical spectrum, most patients with IPD have also other complaints referred to as non-motor symptoms ${ }^{4}$. These non-motor symptoms are the complaints including exhaustion, depression, anxiety, decrease in cognitive capacity, sleep disorders or insomnia, constipation, bladder disfunction, other autonomic disorders (sexual, gastrointestinal) and emotional disorders ${ }^{5,6}$.

In limited number of studies performed it was suggested that psycho-social and economic burden on relatives caring for patients with chronical diseases like IPD is too much and getting higher and higher over time and health status of relatives and the difficulties encountered by relatives be taken into accountduring the diagnosis and in choosing the most appropriate therapeutic options, and if necessary, preventive approaches be considered $^{7,8}$.

In the present study, we aimed at determining the levels of depression, exhaustion, pain and quality of life (QoL) in relatives taking care of patients with IPD, investigating the association of IPD with itsclinical severity and comparing relatives' findings with those of healthy controls.

\section{METHODS}

Sixty patients with the diagnostic criteria for IPD3 and 60 relatives taking care of these IPD patiens constituted our study group, while 50 healthy individuals were included into the control group.Patients with systemic and romatological diseases at a level to affect daily 
Qo, such as ankylosing spondylitis or rheumatoid arthritis, those with the history of major psychiatric disorders, taking antidepressants or anxiolytic drugs, cognitive deficiency, and IPD patients and their relatives not cooperating with the study tests were exclded out of the study.

An approval was obtained from the local ethical board. Patients with IPD and their relatives were informed on the study design, and written consent was obtained from all study participants.

The Unified Parkinson's Disease Rating Scale (UPDRS) scores and the Hoehn-Yahr Scale (HYS) stages were determined in patients with IPD. Depression levels of the relatives and the controls were detected through the Beck's Depression Inventory (BDI), while the pain and exhaustion levels were evaluated via the Visual Analogue Scale (VAS) and the shorth form-36 (SF-36).

The Unified Parkinson's Disease Rating Scale

The Unified Parkinson's Disease Rating Scale, abbreviated as UPDRS, is a scoring system most widely used for the clinical evaluation of IPD, as well as its use in clinical practice to follow the progression of patients' symptoms in a more objective manner. It consists of four divisions as mentation, behavior and mood (a total of 16 points), motor examination (a total of 92 points), daily living activities (a total of 52 points) and complications of therapy (a total of 23 points). In the scale scored between 0 and 4 , an increase observed in total score demonstrates the increase in the symptoms of IPD 9 .

\section{The Hoehn-Yahr Scale}

The HYS is a scale used in the staging of IPD and composed of five stages. As the stages increase, it means that the disease is at advanced level. While stage 0 indicates no finding of the disease, stage 5 means the end- stage, indicating the confinement of patients with IPD to bed ${ }^{10}$.

The Beck's Depression Inventory

The BDI is a valid and reliable instrument used to quantify levels of depressive symptoms in a society. The inventory is composed of 21 items related to depressive symtomps, such as pessimism, mood, dissatisfaction, sense of failure, weeping, tendency to suidical ideas, feeling of guilt, social withdrawal, irritability, insomnia, exhaustion, loss of appetite, weight loss and self-accusation. The BDI is recommended for screening depression symptoms in patients with multiple sclerosis because it is short structure and not confused with neurological smptoms. Each item is scored between $0-3$, and total score changes between $0-63$. In our study, the scores of $\mathrm{BDI} \geq 17$ were assessed in favor of depression. The Turkish version of the BDI was implemented by Hisli et al. The $\mathrm{BDI} \geq 17$ scores were reported to reflect depression ${ }^{11}$.

The Short Form-36, Scale for Quality of Life

The SF-36 includes eight different scales evaluating health status, These eight scales are physical functioning, social functioning, role limitations due to physical health problems, bodily pain, role limitations due to personal or emotional problems, mental health, , energy/fatigue or vitality and general health status. For each scale, the scores of items are coded and converted a point-scale from 0 (poorest health status) to 100 (best health status). According to the scores from subscales, physical and mental subsection points are calculated. The SF-36 has two brief scales as physical component scale, (PCS) and mental component scale (MCS) ${ }^{12}$.

Statistical Analysis

Statistical analyses were performed using SPSS 21.0 package software(Statistical Package for the Social Sciences Inc; Armonk, NY, USA).The data were summarized as mean \pm standard 
deviation (SD). The parametric data of relatives were compared with the student's t test, while non-parametric findings were compared through the chi-square analysis. The association between the clinical features of patients with IPD and those of relatives were assessed with the Spearman's correlation analysis. A p value less than 0.05 was accepted as statistically significant. In terms of correlation coefficients, the values between 0 $0.25,0.25-0.50,0.50-0.75$ and $0.75-1.00$ were evaluated as no correlation, weak-middle, powerful and very powerful correlation, respectively.

\section{RESULTS}

The demographic characteristics of the relatives and the controls in terms of the levels of age, gender, marital status, types of families and educational status were found to be similar and are presented in Table 1.

Table 1: Demographic Characteristics of Relatives and Controls

\begin{tabular}{|l|l|l|c|}
\hline & $\begin{array}{l}\text { Relatives } \\
(\mathrm{n}=60)\end{array}$ & $\begin{array}{l}\text { Controls } \\
(\mathrm{n}=50)\end{array}$ & $\mathrm{p}$ \\
\hline Age (years) & $54.18 \pm 11.55$ & $54.40 \pm 11.11$ & 0.921 \\
\hline $\begin{array}{l}\text { Gender } \\
\text { Male } \\
\text { Female }\end{array}$ & $\begin{array}{l}\% 35(21) \\
\% 65(65)\end{array}$ & $\begin{array}{l}\% 32(16) \\
\% 68(34)\end{array}$ & 0.740 \\
\hline $\begin{array}{l}\text { Marital Status } \\
\text { Married }\end{array}$ & $\begin{array}{l}\% 1.7(55) \\
\text { Unmarried }\end{array}$ & $\begin{array}{l}\% 86(43) \\
\% 10(5)\end{array}$ & 0.275 \\
$\begin{array}{l}\text { Divorced } \\
\% 0(0)\end{array}$ & $\% 4(2)$ & \\
\hline $\begin{array}{l}\text { Type of Family } \\
\text { Nucleus } \\
\text { Extended }\end{array}$ & $\begin{array}{l}\% 91.7(55) \\
\% 8.3(5)\end{array}$ & $\begin{array}{l}\% 84(42) \\
\% 16(8)\end{array}$ & 0.215 \\
\hline $\begin{array}{l}\text { Educational Status } \\
\text { Illiterate } \\
\text { Primary School }\end{array}$ & $\begin{array}{l}\% 18.3(11) \\
\% 58.3(35) \\
\text { High School } \\
\text { College }\end{array}$ & $\begin{array}{l}\% 18(9) \\
\% 58(29) \\
\% 5(3)\end{array}$ & $\begin{array}{l}\text { \%18 (9) } \\
\% 6(3)\end{array}$ \\
\hline
\end{tabular}

While the mean age rate of patients with IPD in the study was found as $67.73 \pm 8.73$, the initial mean age of the disease was detected as $60.20 \pm 10.30$, and the mean disease duration was determined as $7.30 \pm 5.68$ years. The averages of patients' UPDRS and HYE scores were found as $29.26 \pm 15.02$ and $2.27 \pm 1.11$, respectively. The demographic characteristics of patients with IDP are presented in Table 2.

When the relatives were compared with the controls, a statistically significant difference was found in the SF-36 physical, mental and subgroups, and the findings are presented in Table 3.

Table 2: Demographic characteristics of patients with IDP

\begin{tabular}{|l|l|}
\hline & Patients $(\mathrm{n}=60)$ \\
\hline Age & $67.73 \pm 8.73$ \\
\hline Disease Duration & $7,30 \pm 5,68$ \\
\hline Initial Age of Disease & $60,20 \pm 10.30$ \\
\hline Gender & $61.7 \%(37)$ \\
Male & $38.3 \%(23)$ \\
Female & $83.3 \%(50)$ \\
\hline Marital Status & $16,7 \%(10)$ \\
Married & $81.7 \%(49)$ \\
Unmarried & $16.7 \%(10)$ \\
Type of Family & $1.7 \%(1)$ \\
Nucleus & Extended \\
Nursing Home &
\end{tabular}

When the relatives were compared with the controls, a statistically significant difference was found between the values of VAS, exhaustion and depression. Given the threshold of $\mathrm{BDI} \geq 17$, while the depression level was found as $38.3 \%$ among the relatives caring for IPD patients, the depression level was seen as $8 \%$ within the control group. The comparisons between the relatives and the controls are presented in Table 4.

As the UPDRS scores of patients with IPD increased, it was seen that the VAS ( $r=0255)$, BDI $(r=0452)$ and exhaustion $(r=0,276)$ levels also in turn increased while the SF-36 mental ( $r=-0.458)$ ve SF-36 physical $(r=-.0472)$ scores decreased, demonstrating the values of QoL. The positive and negative correlations of the UPDRS scores in the relatives are shown in Table 5. 
Table 3: Values of SF-36 Quality of Life in Relatives and Control Group

\begin{tabular}{|l|l|l|l|}
\hline & Relatives $(\mathrm{n}=60)$ & Controls $(\mathrm{n}=50)$ & $\mathrm{p}$ \\
\hline SF-36 PhysicalComponent & $52.51 \pm 13.19$ & $67.92 \pm 18.27$ & $<0.001$ \\
\hline SF_General_Health & $64.58 \pm 8.40$ & $49.50 \pm 8.46$ & $<0.001$ \\
\hline SF_Pain & $55.04 \pm 16.71$ & $69.00 \pm 23.28$ & 0.001 \\
\hline SF_Social_Functioning & $52.08 \pm 16.78$ & $71.55 \pm 23.02$ & $<0.001$ \\
\hline SF_Emotional_Well-being & $49.60 \pm 12.76$ & $67.44 \pm 16.10$ & $<0.001$ \\
\hline SF-36 MentalComponent & $51.53 \pm 15.51$ & $72.00 \pm 21.62$ & $<0.001$ \\
\hline SF_Role_emotional & $52.22 \pm 34.91$ & $75.33 \pm 39.15$ & 0.002 \\
\hline SF_Fatigue & $52.25 \pm 13.41$ & $73.70 \pm 18.94$ & $<0.001$ \\
\hline SF_Role_Physical & $45.41 \pm 32.70$ & $75.00 \pm 38.79$ & $<0.001$ \\
\hline SF_Physical_Functioning & $45.00 \pm 22.54$ & $78.20 \pm 23.02$ & $<0.001$ \\
\hline
\end{tabular}

\section{DISCUSSION}

Parkinson's disease is a neurodegenerative disease associated with progressive degeneration of nigro-striatal pathways ${ }^{13}$. In describing major clinical characteristics of the disease, James Parkinson defined six main criteria as follows: resting tremor, rigidity, bradykinesia-hypokinesia, flexion posture, loss of postural reflexes and phonemenon of freezing ${ }^{14}$.

As well as an increase seen as to the degree of disability in patients with IPD, especially immobilization is considerably increased due to the adverse effects of drugs used to treat the condition, and daily QoL is affected negatively. Due to these reasons, a great number og patients with IDP may be dependent on the assistance and support of other individuals such as relatives or friends after certain periods of their disease ${ }^{15}$.

Previous studies related to patients with Parkinson's disease have mostly investigated how and at what levels QoL of such patients depending on motor and non-motor symptoms are affected ${ }^{16-18}$, but the attention to QoL of the relatives/friends is paid less.
The term "load on the relatives/friends" is used to describe physical, psychological, social and economic difficulties and burdens experienced while offering medical care and assistance ${ }^{19}$. Becoming a relative or a friend caring for a patient requiring for others' medical support and assistance is an unplanned and unchosen condition out of our own will20. Frustration and tension arising from long-term care lead to irreversible results in both the relatives/friends and patients' health status. Negative consequences of long-term caring load on individuals may also have changeable features from a society to another, as chanbeable from an individual to another ${ }^{21}$. Caring for patients was reported to be associated with the development of psychological and physiological problems. In addition, it is a well-known entity that health status of the relatives/friends may be distorted due to long-tem care ${ }^{22}$. Among the relatives/friens caring for a patient, $60.6 \%$ are reported to have no timedevoted to themselves due to caring load, $78.8 \%$ to feel themselves exhausted, $84.9 \%$ to experience difficulties in communication with patients they cared for, and $56.9 \%$ to be in financial difficulties ${ }^{23}$. The importance given to the relatives/friends caring for IPD patients is increasing day by day 
and better-understood ${ }^{24}$. Studies in literature demonstrate that the burnout level is also increased along with the deterioration of physical and psychological health status in the relatives/friends, especially caring for patients with neurological diseases, such as stroke, Parkinson's and Alzheimer's ${ }^{25,26}$. In a study performed by Lökk, it was recommended that psycho-social and economic burdens on the individuals caring for patients with chronical diseases like IDP are so much, such burdens increase over time, health status and difficulties experienced by the relatives/friends within the follow-up period be taken into account, and if necessary, preventive approaches be considered $^{8}$. In another study conducted by Yilmaz et al., it was asserted that the relatives/friends are insidiously sick, and negative physical, psychological and social challenges experienced within the caring period affect these relatives/friends themselves intensively ${ }^{25}$.

Table 4: Values of Visual Analogue Scale, Exhaustion and Beck's Depression Inventory in Relatives and Control Group

\begin{tabular}{|l|l|l|c|}
\hline & $\begin{array}{l}\text { Relatives } \\
(\mathrm{n}=60)\end{array}$ & $\begin{array}{l}\text { Controls } \\
(\mathrm{n}=50)\end{array}$ & $\mathrm{p}$ \\
\hline VAS & $5.18 \pm 2.23$ & $2.90 \pm 1.78$ & $<0.001$ \\
\hline Exhaustion & $4.90 \pm 2.63$ & $2.98 \pm 1.90$ & $<0.001$ \\
\hline BDI & $13.21 \pm 11.09$ & $6.88 \pm 6.27$ & $<0.001$ \\
\hline
\end{tabular}

VAS: Visual Analogue Scale, BDI: Beck's Depression Inventory

Table 5: Correlated Features of UPDRS scores of Relatives and Control Group

\begin{tabular}{|l|c|c|}
\hline & $\mathrm{P}$ & $\mathrm{R}$ \\
\hline VAS of Relatives & 0.049 & 0.255 \\
\hline Exhaustion of Relatives & 0.033 & 0.276 \\
\hline BDI of Relatives & 0.000 & 0.452 \\
\hline SF-36 Physical of Relatives & 0.000 & -0.472 \\
\hline SF-36 Mental of Relatives & 0.000 & -0.458 \\
\hline
\end{tabular}

VAS: Visual Analogue Scale, BDI: Beck's Depression Inventory, SF-36: Life quality scale
Depression is also one of the negative problems led by long-term caring period, decreasing QoL and causing functional deterioration in the relatives/friends caring for patients in need of assistance and support ${ }^{27}$. In their study,Pablo Martinez-Martin and co-workers revealed that patients' disability level determined by the assessment of daily living activities (DLA) scale is the most significant factor showing the stress level and psycho-social burden on the relatives/friends ${ }^{28}$. In the same way, we demonstrated that depression levels were significantly higher in the relatives/friends, compared with the controls, and depression levels in the reletives/friends were also positively correlated with the disease severity determined through the UPDRS score. For this reason, while the depression status of chronically ill patients is evaluated, the relatives/friends' status should be kept in mind, and when diagnosed with depression, patients should be referred to necessary health centers.

Also previous studies reported that QoL was deteriorated in the relatives/friends caring for IPD patients and as the disease severity increased a significant decrease was seen in QoL of the relatives/friends ${ }^{28}$. As consistent with the findings of this study, depression, exhaustion and pain levels of the relatives/friends detected through the UPDRS scores showed a similar correlation. Additionally, QoL parameters of the relatives/friends were also found to be significantly lower than the controls and to show a negative correlation with the disease severity. These findings suggest that QoLis also definitely affected in a negative way in the relatives/friends caring for IPD patients. 


\section{CONCLUSION}

IPD is a disease affecting both IPD patients and the relatives/friends lives considerably and decreasing QoL significantly. Not only IPD patients but their relatives/friends are also affected on a large scale. So, during the diagnosis and follow-up periods, not only should the care be concentrated on patients, but QoL and psychological status of the relatives/friends should also be evaluated. We consider that the quality of caring process can be increased with counseling for the needs of patients with IPD and their relatives/friends, the stress and caring load on the relatives/friends can be reduced, and QoL of IPD patients can be elevated.

Declaration of Conflicting Interests: The authors declare that they have no conflict of interest.

Financial Disclosure: No financial support was received.

\section{REFERENCES}

1. De Rijk MC, Breteler MM, Graveland GA, Ott A, et al. Prevalence of Parkinson's disease in the elderly: the Rotterdam Study. Neurology 1995; 45:2143-46.

2. Cookson MR, Xiromerisiou G, Singleton A. How genetics research in Parkinson's disease is enhancing understanding of the common idiopathic forms of the disease. Curr Opin Neurol 2005; 18:706-11.

3. Teive HA, Bertucci DC Filho, Munhoz RP. Unusual motor and non-motor symptoms and signs in the early stage of Parkinson's disease. Arg Neuropsiquiatr. 2016 Oct; 74:781-84.

4. Chaudhuri KR, Healy DG, Schapira AH. Non-motor symptoms of Parkinson's disease: Diagnosis and management. Lancet Neurol 2006; 5:235-45.

5. Fahn S, Jankovic J. Principles and Practice of Movement Disorders, Churchill Livingstone/Elsevier, 2007.

6. Haluk Gümüş, Zehra Akpınar, Orhan Demir. Assessment of Early Stage Non-Motor Symptoms in Parkinson's Disease TJN 2013; 19;3.

7. Morimoto T, Schreiner AS, Asano H. Caregiver burden and health-related quality of life among Japanese stroke caregivers. Age Ageing 2003; 32:218-23.
8. Lökk J. Caregiver strain in Parkinson's disease and the impact of disease duration. Eur J Phys Rehabil Med 2008; 44:39-45.

9. Ramaker C, Marinus J, Stiggelbout AM, et al. Systematic evaluation of rating scales for impairment and disability in Parkinson's disease. Mov Disord 2002; 17:867-76.

10. Hoehn MM, Yahr MD. Parkinsonism: Onset, progression, and mortality. Neurology 1967; 17:42742.

11. Hisli N. Beck depresyon envanterinin gecerliliği üzerine bir calışma. Psikoloji Dergisi 1988; 22:118-26. Hisli N. A study on the validity of Beck depression inventory. Psikoloji Dergisi 1988; 22:118-26.

12. Ware JE Jr. SF-36 health survey update. Spine (Phila Pa 1976) 2000; 25:3130-39

13. J. Peron, T. Dondaine, F. Le Jeune, et al. Emotional processing in Parkinson's disease: a systematic review, Mov. Disord. 27:2012; 186-99.

14. Rowland LP, Pedley TA, Merritt HH. Movement Disorders. In Rowland LP (editor) Merritt's Neurology. Eleventh ed. Lippincott Williams \& Wilkins 2008; 7989.

15. Vicki T. Lampley-Dallas, James W. Mold, Denise E. Flori. Perceived needs of African-American caregivers of elders with dementia. J Natl Med Assoc 2001; 93:4757.

16. Aarsland D, Larsen JP, Lim NG et al. Range of neuropsychiatric disturbances in patients with Parkinson's disease. J Neurol Neurosurg Psychiatry 1999; 67:492- 96.

17. K Ray Chaudhuri. Parkinson's Disease and Quality of Life - A Clinician's Perspective. European Neurological Review, 2011; 6(Suppl. 1):9-12.

18. Slawek J, Derejko M, Lass P. Factors affecting the quality of life of patients with idiopathic Parkinson's Disease: a cross sectional study in an outpatient clinic attendees. Parkinsonism Relat Disord 2005; 11:46568.

19. Zarit SH, Reever KE, Bach-Peterson J. Relatives of the impaired elderly: Correlates of feelings of burden. Gerontologist 1980; 20:649-55.

20. Eicher PS, Batshaw ML. Cerebral palsy. Pediatr Clin North Am 1993; 40:537-51.

21. Murat İlhan Atagün, Özlem Devrim Balaban, Zeliha Atagün, et al. Caregiver Burden in Chronic Diseases. Psikiyatride Güncel Yaklaşımlar-Current Approaches in Psychiatry 2011; 3:513-52. 
22. Dunkin JJ, Anderson-Hanley C. Dementia caregiver burden: a review of the literature and guidelines for assessment and intervention. Neurology 1998; 51:5360.

23. Larsen LS. Effectiveness of a counseling intervention to assist family caregivers of chronically ill relatives. J Psychosoc Nurs Ment Health Serv 1998; 36:26-32.

24. Pablo Martinez-Martin, Julian Benito-Leon , Fernando Alonso,et al. Quality of life of caregivers in Parkinson's disease. Qual Life Res 2005; 14:463-72.

25. Yllmaz A, Turan E, Gundogar D. Predictors of burnout in the family caregivers of Alzheimer's disease: evidence from Turkey. Australas J Ageing 2009; 28:1621.
26. Yaffe K, Fox P, Newcomer R, et al. Patient and caregiver characteristics and nursing home placement in patients with dementia. JAMA 2002; 287:2090-97.

27. Stommel M, Collins CE, Given BA. The costs of family contributions to the care of persons with dementia. Gerontologist 1994; 34:199-205.

28. Martinez-Martin P, Guerrero MT, Frades B,et al. Quality of life of caregivers: A new perspective on the consequences of Parkinson's disease. Mov Disord 1998; 13(Suppl 2:63. 